MUDRA: Journal of Finance and Accounting Volume 4, Issue 1, January-June 2017, pp. 102-121 doi: 10.17492/mudra.v4i01.9782

\title{
A Comparative Evaluation of NPAs Recovery Mechanisms by Public Sector Banks in India
}

\author{
Lovleen Gupta* and Mridul Dharwal**
}

\begin{abstract}
A consistent increase in Non-performing assets (NPA) in the financial statements of various public sector banks has put several questions before policy makers and regulatory institutions with regard to functioning of banking system in India. Besides reflecting deteriorating financial health of banks, it also restricts the liberty of banks in adopting new strategies towards growth. Rather banks are required to adopt conservative approach in sanctioning new loans till the problem of NPAs is reasonably resolved. This study examines the growth of NPAs during the period 2001-02 to 2012-13 in public sector banks in India and the effectiveness of Lok Adalats, Debt Recovery Tribunals and SARFAESI Act, 2002 in solving the problems of NPAs.
\end{abstract}

Keywords: Non-performing assets; Lok Adalats; Debt recovery tribunals; SARFAESI Act; Public sector banks.

\subsection{Introduction}

The most important implication of the NPA is with regard to its treatment in the financial records of the banks. A bank can neither credit the income nor debit it as loss, unless either recovered or identified as loss. Further, if a borrower has number of with the bank then, all accounts would be considered as NPA if even one account happens to be NPA. Due to NPAs, the owners of banks will not receive a market return on their capital. In case the bank fails, the owners would lose their assets. In the present scenario, this could negatively impact at bank's shareholders wealth. The bank will fail to deliver market return on savings of its depositors. In case the bank fails, depositors would lose their assets or uninsured balance.

*Corresponding author; Assistant Professor, Department of Commerce, Hindu College, University of Delhi, Delhi, India. (Email id: lovleen15_gupta@yahoo.co.in)

**Associate Professor in Economics, Sharda University, Greater Noida, Uttar Pradesh, India. (Email id:mridualdharwal22@gmail.com) 
In order to recoup losses, banks will tend to redistribute losses to other borrowers by charging higher interest rates. The phase of lower deposit rates and higher lending rates would adversely affect the savings and financial markets, which will act as an obstacle to the economic growth. As already mentioned, Non-performing loans can be a synonym to bad investments which has resulted due to misallocation of credit from good projects, which could not receive funding due to failed projects. NPAs not only lead to misallocation of capital but also misallocation of other resources such as labour, material and natural resources. The economy performs below its production potential. The problem of non-performing loans could spill over the banking system and may lead to contraction of the money stock thereby finally giving way to financial crisis. This can happen because many borrowers fail to pay interest and banks begin to experience liquidity shortages. These shortages results into payment problems across the country. Due to illiquidity, banks are unable to pay depositors which can then lead to financial panic.

\subsection{Review of Literature}

Joshi (2000) pointed out the reasons behind the emergence of NPA's and steps taken by Govt. for their recovery. He was of the view that interest earned on advances should always be more than interest paid on deposits as a matter of sound banking policy. Sharma (2001) examined the hypothesis that the problem of NPA's of Indian banks remained unsolved because of improper sequencing of reforms. She suggested the proactive approach towards the legislative, infrastructural and regulatory reforms to prevent build-up of NPAs in future. In many studies, NPAs are taken as one of the factor while deciding to put money in the bank. The declining NPA's of Indian banks has prompted S\&P to revise its outlook on the Indian banking system to 'stable' from 'negative'.

Joshi (2003) conducted a survey on 'NPAs of IFCI Ltd'. The study found that profitability and viability of development of Financial Institutions are directly affected by quality and performance of advances. Jain (2007) examined the status of NPAs in Scheduled commercial banks in India. The study found that there is more acute problem of gross and net NPAs in Indian Public sector Banks. The new private sector banks and foreign banks have also shown an increasing trend of gross and net NPAs during 19972003. It concluded that new private sector and foreign banks failed to prevent this problem but public sector and old private sector banks succeed in reducing it over a period of time. Singla (2008) studied the financial performance of banks in India in view of increasing globalisation and increased competition in Indian banking industry for a 
period of six years 2001-2006. He concluded that NPAs have shown declining trend over a period of time under study.

Rajeev and Mahesh (2010) explored the trends of NPAs in India from various dimensions and explained how mere recognition of the problem and self-monitoring has been able to reduce it to a great extent. The paper also shows that public sector banks in India, which function to some extent with welfare motives, have as good a record in reducing NPAs as their counterparts in the private sector. It is advised that the self-help group model can be applied to some of the sectors to help the poor access loans and ensure repayment for the banks. Gurumoorthy and Sufha(2012) analysed that in the liberalised economy, banking and financial sector get higher priority. The banks in India are facing the problems of NPAs. The earning capacity and profitability of banks are highly affected because of the existence of NPAs. Moreover, the non-performance of non-receipt of interest and principal blocked banks money in the form of funds and is not available for further use of banking business and thus the profit margin of the banks goes down. In this connection banks must be aware of the problems and recovery of legislation of NPAs. Shalini (2013) suggests that credit management includes planning, organizing, controlling, directing and coordinating the credit sanctioning policies in order to decrease the NPAs.

Mahajan (2014) studied the concept of NPA and its trend over a period of years for public, private and foreign sector banks in India. It was found in the study that the position of NPAs is improving in India although NPAs are having a declining trend over a period of study, but Non Performing Assets of public sector banks are still higher than private and foreign sector banks. It was further explored that top management of private and foreign sector banks is more professional, core competent and expertise than public sector banks. So, they are more competent in making plans for recovering funds from borrowers (both individuals and institutional). Satpal (2014) conducted a study to gain insights into the position of NPAs of all commercial banks categories in public sector, private sector, Scheduled commercial banks and foreign banks. It was found that the problem of NPAs needs a lot of serious effort otherwise NPAs will keep killing the profitability of banks which is not good for the growing Indian economy at all. Therefore, the government should also make more provisions for faster settlement of pending cases and also it should reduce the mandatory lending to priority sector as this is the major problem creating area. Rao and Patel (2015) examined the non-performing assets management with reference to public sector banks, private sector banks and foreign banks in India and also analysed various NPA related ratios for aggregates of public sector, private sector and foreign banks in India from 2009-2013. The findings revealed that the percentage of gross NPA to gross advances is increasing for public 
banks, ratio of loss advances to gross advances are higher in foreign banks, the estimated gross NPA for 2014 is also more in public banks as compared to private and foreign banks and from the ANOVA test, it is concluded that ratio of gross NPA to gross advances for public sector, private sector and foreign banks does not have significant difference between 2009 to 2013.

Laveena and Guleria (2016) analysed NPA problems and understanding the causes of it and also discussed about magnitude and also the causes of NPA problem over the last 3 years and its effect on economy. It was found that market failures, wilful defaults, poor follow up, poor supervision, diversion of funds are some of the prominent reasons for NPA in banks. It was advised that banks must pay proper attention regarding the borrower that has come for loan and analyse his/her financial statements thoroughly to avoid any complications in future that may lead to NPA. Singh (2016) made an attempt to understand NPA, the status and trend of NPAs in Indian Scheduled commercial banks, the factors contributing to NPAs, reasons for high impact of NPAs on Scheduled commercial banks in India and recovery of NPAs through various channels. It was found that the NPA level of Indian banks is still high as compared to the foreign banks. Although, it is not at all possible to have zero NPAs but still the bank management should speed up the recovery process. They also commented that the problem of recovery is not with small borrowers but with large borrowers and a strict policy should be followed for solving this problem. It was advised that the government should also make more provisions for faster settlement of pending cases and also it should reduce the mandatory lending to priority sector as this is the major problem creating area.

Kumar (2017) evaluated the effectiveness of DRTs, Lok Adalats SARFAESI Act in the recovery of NPAs during the year 2006 to 2015. For the research financial statistical tool, correlation, regression has been used to explain the relationship between amount of NPA and its recovery. The study shows that percentage of recovery in terms of amount and number of cases referred to these channels denotes that SARFAESI Act 2002 and DRT do not have larger variations. Lok Adalats function by amicably settling disputes that are pending in a court of law or at a pre-litigation stage. This defines that DRTs and SARFAESI Act is much more efficient to recover the NPAs. While comparing the number of cases referred to Lok Adalats cover almost 80 percent on an average per year. Besides this in terms of amount recovered their performance is not so good. The reason may be that these court deals with a large number of cases involving smaller amounts having an individual ceiling. 


\subsection{Growth of NPAs}

Various steps have been taken since Independence to ensure the benefit of banking system among the large segment of society. Government took several initiatives so that the benefit of banking system is not restricted to few individuals or industrialist rather they perform and justify their presence for the purpose for which they have been created. Nationalisation of banks was one of the major step taken in this direction and subsequently different committees were set up like Tandon and Chore Committee, Narsimham Committee ,etc to improve the functioning of banks. Among the various recommendations given by Narsimham Committee, one of the important recommendations was in respect of categorisation of loans extended by banks into standard, sub-standard and doubtful category. A loan is classified as Non-performing asset if the interest or any principle repayment remains unpaid for a period exceeding 180 days. Such assets are required to be reflected in the financial statements of banks. A trend of NPAs in public sector banks in India during the period 2001-02 to 2012-13 is mentioned in Table 1.

Table 1: Trend of NPAs in Public Sector Banks in India

\begin{tabular}{|l|c|c|}
\hline Year & $\begin{array}{l}\text { Gross NPA as \% of Gross Advances } \\
\text { (PSB) }\end{array}$ & $\begin{array}{l}\text { Net NPA as \% of Net Advances } \\
\text { (PSB) }\end{array}$ \\
\hline $2001-02$ & 11.1 & 5.8 \\
\hline $2002-03$ & 9.4 & 4.5 \\
\hline $2003-04$ & 7.8 & 3.1 \\
\hline $2004-05$ & 5.5 & 2.1 \\
\hline $2005-06$ & 3.6 & 1.3 \\
\hline $2006-07$ & 2.7 & 1.1 \\
\hline $2007-08$ & 2.2 & 1 \\
\hline $2008-09$ & 2 & 0.9 \\
\hline $2009-10$ & 2.2 & 1.1 \\
\hline $2010-11$ & 2.4 & 1.2 \\
\hline $2011-12$ & 3.2 & 1.5 \\
\hline $2012-13$ & 3.6 & 2 \\
\hline
\end{tabular}

Source: RBI Bulletin 
It can be observed from Table 1 that Gross NPA as \% of Gross Advance as well as Net NPA of Net Advance have shown decreasing trend during the period $2001-02$ to 2012-13. The period 2001-02 to 2007-08 witnessed sharp fall in the entire banking sector. However, thereafter, the level of NPAs has shown marginal change. In order to address these issues, the recovery mechanisms such as Lok Adalats, Debt Recovery Tribunals and SARFAESI Act, 2002 are being employed. Their features and effectiveness in resolving problems of NPAs is discussed below.

\subsection{Lok Adalats}

These are legal recourse organised by National Legal Services Authority under Legal Services Authorities Act, 1987 which aims to provide a platform for amicable settlement of disputes between lender bank and borrower when the borrower fails to pay his dues to the banks. These are organised in various districts. Lok Adalats are vested with the same powers as that of Civil courts. Once the application with regard to dispute between two parties, Lok Adalat can proceed only if it feels that there are chances of arriving at amicable resolution. Lok Adalat is conferred with following powers, while deciding any case:

i) It can summon or enforce attendance of any witness;

ii) It can examine the witness on oath;

iii) It can direct for production of any document by either party or both;

iv) It can obtain any additional information from any other office.

Lok Adalats can take up the cases which are pending as litigation in any court or which are in the pre litigation stage. The decision given by LokAdalats is referred as 'decree' which can be executed in the court. In the past, such mechanisms have been effective in recovering NPAs of approximately $11 \%$ for the case referred by Reserve Bank of India. According to one of the report in Business Line dated 20 November, 2013, Lok Adalats were entrusted with the task of recovering Rs 1700 croreswhich were existing as NPAs in the books of different banks. Lok Adalats were able to recover Rs 200 crore amounting to approximately $11.8 \%$ of the total amount. One of the sponsored regional rural bank of Syndicate bank, namely Karnataka Vikas Grameena Bank found this mechanism very effective as the bank was able to settle 1412 cases out of 4165 pending cases in just three months' time i.e. from Sept 1 to Dec 5, 2014. The total amount involved in such cases was around Rs 10.78 crores of which Rs 1.8 crore was recovered immediately and the remaining was due to be recovered through instalments amicably settled with the borrowers. 


\subsection{Main features of Settlement of dues through Lok Adalat}

The main features of the scheme are highlighted below:

- The scheme was mainly intended to recover dues from farmers, educational loan and property loans.

- Concession was given on penalty and interest on the loan for those who were ready to settle their dues.

- The decision with regard to final settlement is arrived through mutual consent.

- The settlement process is hassle free as large number of camps is available and borrower has easy access to the bank official.

- The process saves lot of time for the borrower as well as the lender bank.

- Loan having value up to Rs 20 lakhs can be settled through Lok Adalats.

- The decision of Lok Adalats in the form of decree or award can be executed in the civil courts.

Table 2 provides details of the number of cases referred to Lok Adalat from 2003-04 to 2011-12 along with diagrammatic representation in Figure 1.

Table 2: Number of NPA Cases referred to in Lok Adalats

\begin{tabular}{|c|c|}
\hline Year & Number of Cases Referred \\
\hline $2003-04$ & 186100 \\
\hline $2004-05$ & 185395 \\
\hline $2005-06$ & 268090 \\
\hline $2006-07$ & 160368 \\
\hline $2007-08$ & 186535 \\
\hline $2008-09$ & 548308 \\
\hline $2009-10$ & 778833 \\
\hline $2010-11$ & 616018 \\
\hline $2011-12$ & 476073 \\
\hline
\end{tabular}

Source: Report on Trend and Progress of Banking in India, various issues, RBI.

It can be observed from Figure 1 and Table 2 that number of cases referred to Lok Adalats significantly increased during the period 2008-09 and 2009-10 as compared to their previous years. This may be attributed to sudden downtrend in GDP growth rate after global recession. During the same period, the details regarding amount involved in the cases and amount recovered is given in Table 3 and Figure 2. 
Figure 1: Number of Cases Referred to Lok Adalat

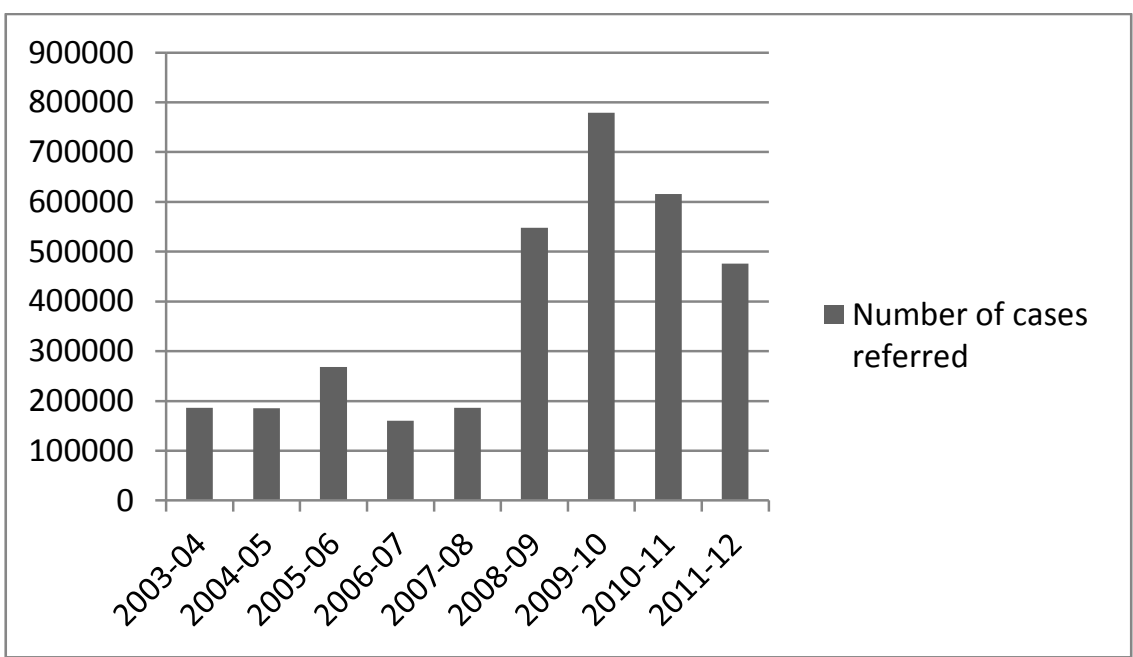

Source: Report on Trend and Progress of Banking in India, various issues, RBI

Table 3: Amount involved in NPAs and Recovered under Lok Adalat

\begin{tabular}{|c|c|c|}
\hline Year & Amount Involved & Amount Recovered \\
\hline $2003-04$ & 1063 & 149 \\
\hline $2004-05$ & 801 & 113 \\
\hline $2005-06$ & 2144 & 265 \\
\hline $2006-07$ & 758 & 106 \\
\hline $2007-08$ & 2142 & 176 \\
\hline $2008-09$ & 2215 & 179 \\
\hline $2009-10$ & 7235 & 112 \\
\hline $2010-11$ & 5300 & 200 \\
\hline $2011-12$ & 1700 & 200 \\
\hline
\end{tabular}

Source: Report on Trend and Progress of Banking in India, various issues, RBI

From Table 3, one can observe that the amount involved has sharply increased in the year 2009-10 where in the preceding years, the amount involved has remain almost in the same level. In order to assess the effectiveness of Lok Adalat, ratios for different years has been calculated using the formula given below:

Efficiency of Lok Adalat in recovering dues $=($ Amount recovered $/$ Amount involved $) \times 100$ 
Figure 2: Amount involved in NPAs and Recovered under Lok Adalat

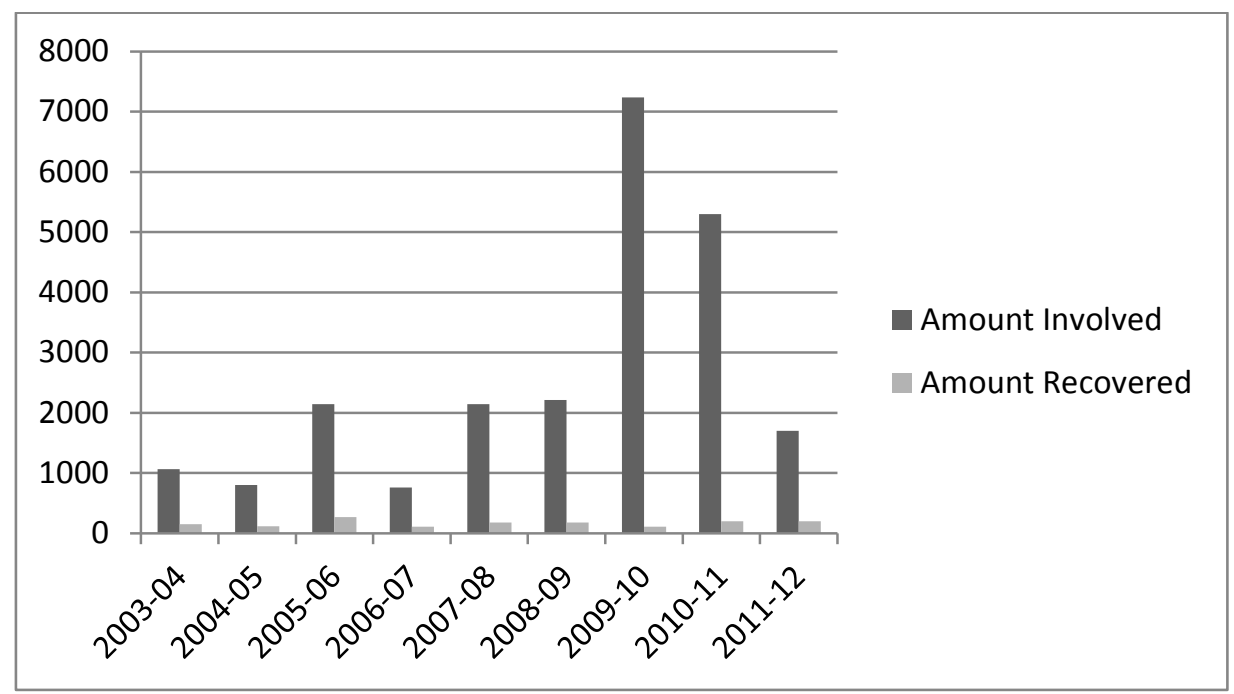

Source: Report on Trend and Progress of Banking in India, Various issues, RBI

Note: **refers to amount recovered during the given year which could be with reference to cases referred during the given year as well as during the earlier years.

As per data given in Table 4 and Figure 3, it can be seen that in the initial years, this mechanism has proved to be more effective in recovery of non-performing loans. Around 11 to14\% of the amount involved could be recovered in most of the years except the period 2007-08 to 2010-11. This could be due severe recession period on account of global financial crisis.

Table 4: Percentage of Recovery relative to Amount involved under Lok Adalat

\begin{tabular}{|c|c|}
\hline Year & Percentage of recovery relative to amount involved \\
\hline $2003-04$ & 14.01 \\
\hline $2004-05$ & 14.1 \\
\hline $2005-06$ & 12.36 \\
\hline $2006-07$ & 13.98 \\
\hline $2007-08$ & 8.21 \\
\hline $2008-09$ & 8.21 \\
\hline $2009-10$ & 1.54 \\
\hline $2010-11$ & 3.77 \\
\hline $2011-12$ & 11.76 \\
\hline
\end{tabular}

Source: Report on Trend and Progress of Banking in India, Various issues, RBI 
Figure 3: Percentage of Recovery relative to Amount involved under Lok Adalat

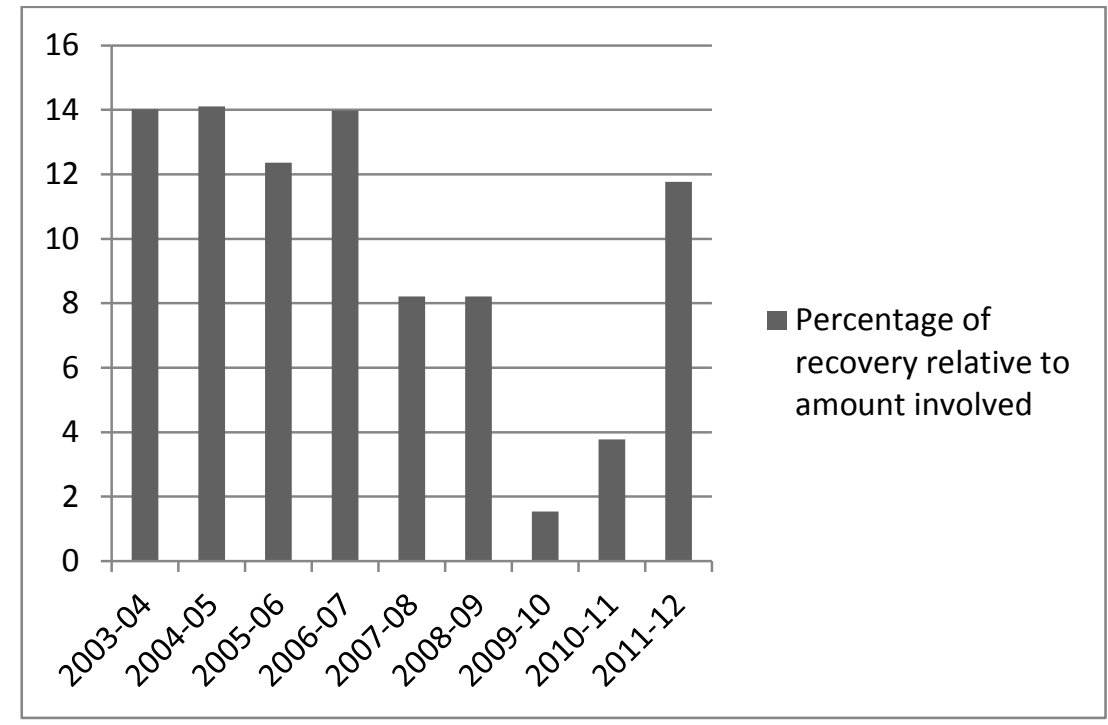

Source: Report on Trend and Progress of Banking in India, various issues, RBI

It can be observed from Figure 3 that the efficiency of Lok Adalats has almost remained same over the period 2003-04 to 2006-07. However, the efficiency of Lok Adalats decreased significantly during the year 2009-10 and thereafter it has gradually picked up. The reason which can be attributed to this aspect is the significant increase in the amount involved and marginal decrease in the amount recovery in comparison to preceding years.

\subsection{Debt Recovery Tribunal}

Among the various measures available for banks to recover their funds blocked in form of Non-Performing Assets, one of them is through Debt Recovery Tribunal. The Debt Recovery Tribunals are constituted by district courts and it enjoys all the powers of a court. The banks can approach Debt Recovery Tribunal (DRT) for recovering its dues held in form of NPAs as per definition given by Reserve Bank of India. The tribunal appoints a officer which assist the banks in the recovery process. The tribunal has powers to summon the party in default and can also require production of additional documents, if the same is required. In the initial years, the constitution of DRT mechanism proved effective in resolving problems of NPAs but subsequently the effectiveness of the DRT gradually decreased because most of the parties used cross 
litigation as excuse for not following DRT directions. Most of the borrowers used to take the plea that since the case is pending in civil court therefore DRTs have no jurisdiction to take over such cases. In fact, in the initial years, when DRT was proving effective, State level banks extended their lending capacity because they are confident that their dues are unlikely to be held as NPA since DRT would help them in the event their dues are blocked. It can be observed from the statistical detail, given below, that number of cases referred to DRT significantly increased in the year 2009-10 in comparison to preceding years. The details of number of cases referred under Debt Recovery Tribunal during the period 2003-04 to 2011-12 are given in Table 5. In order to have better understanding of the above data, bar chart corresponding to above data is given in Figure 4 below.

Table 5: Number of Cases referred under Debt Recovery Tribunal during 2003-04 to 2011-12

\begin{tabular}{|c|c|}
\hline Year & Number of cases referred \\
\hline $2003-04$ & 186100 \\
\hline $2004-05$ & 185395 \\
\hline $2005-06$ & 268090 \\
\hline $2006-07$ & 160368 \\
\hline $2007-08$ & 186535 \\
\hline $2008-09$ & 548308 \\
\hline $2009-10$ & 778833 \\
\hline $2010-11$ & 616018 \\
\hline $2011-12$ & 476073 \\
\hline
\end{tabular}

Source: Report on Trend and Progress of Banking in India, various issues, RBI

It can be observed that the number of cases referred in DRTs have remained at low level during the period 2003-04 to 2007-08. In the subsequent period i.e. 2008-09 to 2011-12, the numbers of cases referred have quite significantly increased because of the increasing popularity of DRT among banks in recovery of NPA and also the focus of banks in improving their balance sheets through recovery of NPAs. The detail of the amount involved and the amount recovered under Debt Recovery Tribunal during the period 2003-04 to 2011-12 is given in Table 6. The above information has been displayed through bar chart in Figure 5. 
Figure 4: Number of Cases referred under Debt Recovery Tribunal during 2003-04 to 2011-12

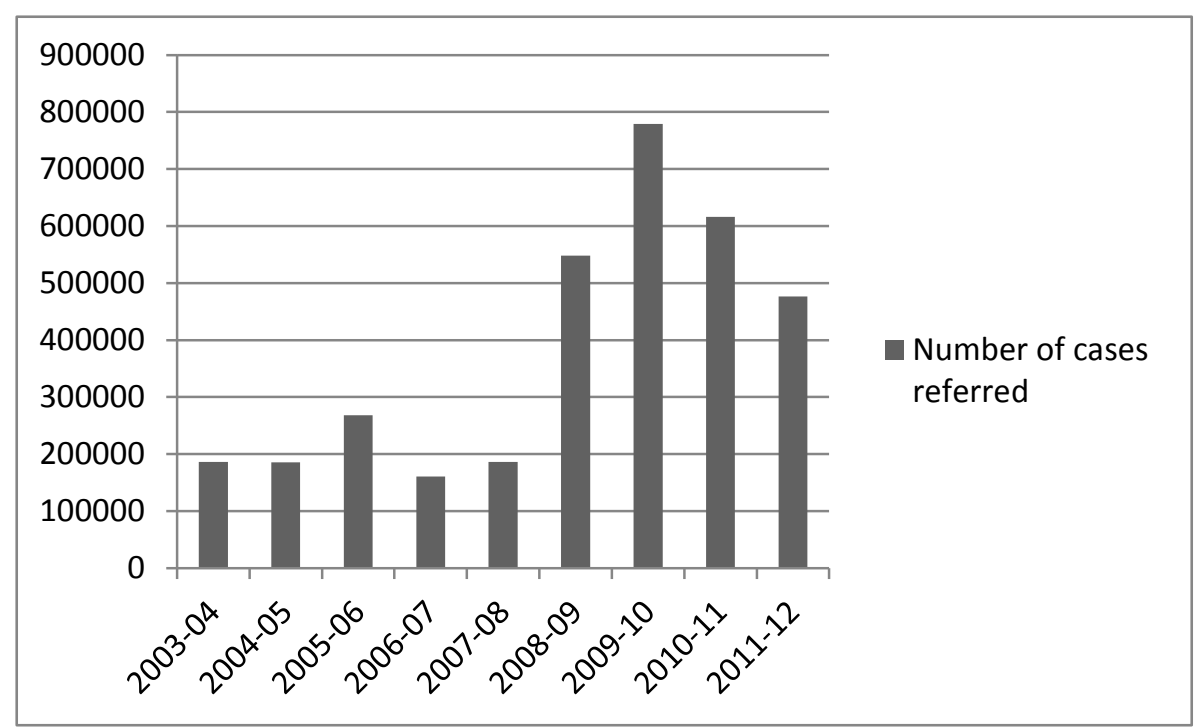

Source: Report on Trend and Progress of Banking in India, various issues, RBI

Table 6: Amount involved in NPAs and Recovered under Debt Recovery Tribunal

\begin{tabular}{|c|c|c|}
\hline Year & Amount Involved & Amount Recovered \\
\hline $2003-04$ & 1063 & 149 \\
\hline $2004-05$ & 801 & 113 \\
\hline $2005-06$ & 2144 & 265 \\
\hline $2006-07$ & 758 & 106 \\
\hline $2007-08$ & 2142 & 176 \\
\hline $2008-09$ & 2215 & 179 \\
\hline $2009-10$ & 7235 & 112 \\
\hline $2010-11$ & 5300 & 200 \\
\hline $2011-12$ & 1700 & 200 \\
\hline
\end{tabular}

Source: Report on Trend and Progress of Banking in India, Various issues, RBI 
The efficiency of the Debt recovery tribunals is assessed using the formula given below:

Efficiency of DRT in recovering dues = (Amount recovered / Amount involved $) \times 100$

Using the data given in Table 6 , the percentage of recovery has been calculated for the period 2003-04 to 2011-12 in Table 7 and the same is presented graphically in Figure 6.

Figure 5: Amount involved in NPAs and Recovered under Debt Recovery Tribunal

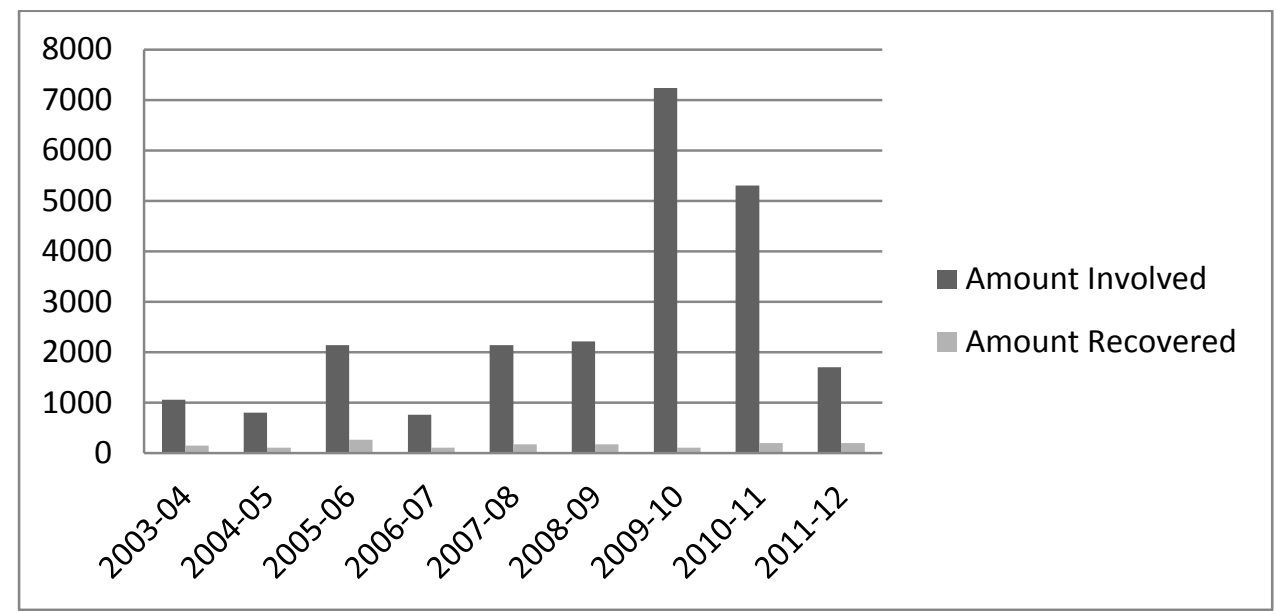

Source: Report on Trend and Progress of Banking in India, Various issues, RBI

Table 7: Percentage of recovery relative to amount involved under Debt Recovery Tribunal

\begin{tabular}{|c|c|}
\hline Year & Percentage of recovery relative to amount involved \\
\hline $2003-04$ & 17.2 \\
\hline $2004-05$ & 18.77 \\
\hline $2005-06$ & 75.48 \\
\hline $2006-07$ & 37.82 \\
\hline $2007-08$ & 51.89 \\
\hline $2008-09$ & 50.85 \\
\hline $2009-10$ & 31.97 \\
\hline $2010-11$ & 27.65 \\
\hline $2011-12$ & 17.01 \\
\hline
\end{tabular}

Source: Report on Trend and Progress of Banking in India, various issues, RBI 
Figure 6: Percentage of Recovery Relative to Amount involved under Debt

\section{Recovery Tribunal}

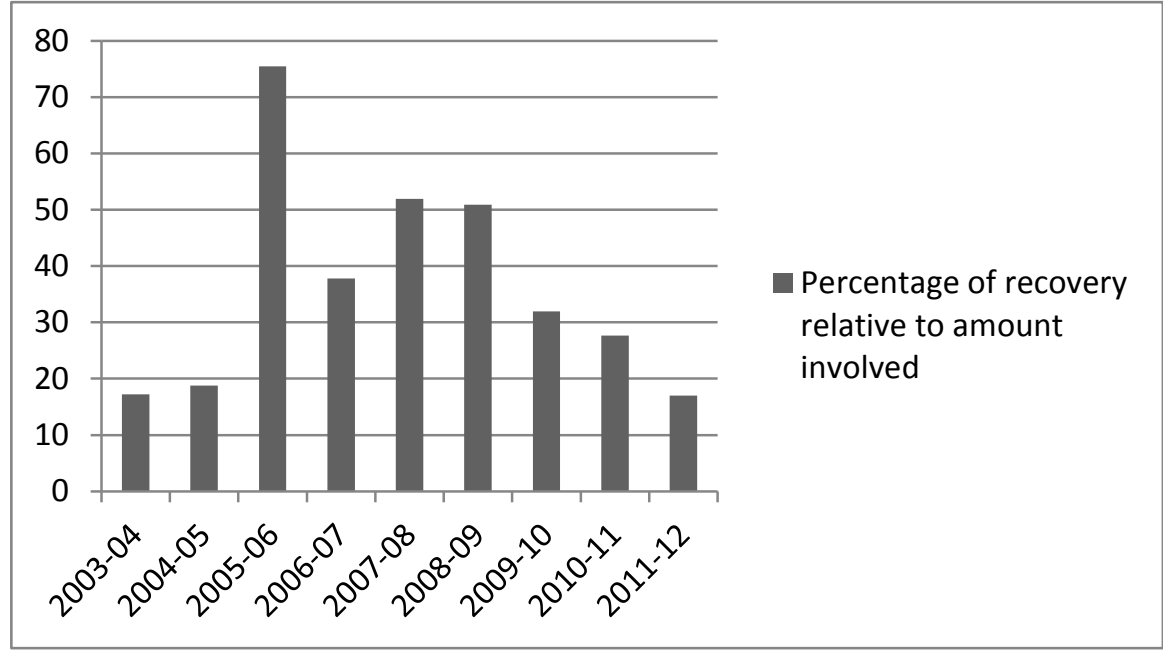

Source: Report on Trend and Progress of Banking in India, various issues, RBI

It can be observed from Table 7 and Figure 6 that in the initial years, this mechanism has not proved to be more effective in recovery of non-performing loans. However, in the subsequent years, the recovery has improved. The performance of the DRT was remarkable during the period 2005-06 to 2009-10. In the subsequent years, the performance of DRTs have gradually declined and the reasons which can be attributed are discussed below.

\subsection{Challenges before Debt Recovery Tribunals in recovering NPAs}

- In most of the cases, the borrower has filed cases with civil courts and therefore challenges the role of DRT in proceeding in the matter.

- Conflict of role between Official liquidator and recovery agent appointed by DRT arises and leads to delay in resolution of the problem.

- The enactment of SARFAESI Act, 2002 (The Securitization and Reconstruction of Financial Assets \& Enforcement of Security Interest Act, 2002) has provided alternative mechanism for banks to recover dues.

- Borrowers generally appeal for one time settlement scheme and intend to move from Debt recovery tribunal.

- There is no time limit specified for resolving the complaints. 
116 | MUDRA: Journal of Finance and Accounting, Volume 4, Issue 1, Jan-Jun 2017

\subsection{The Securitization and Reconstruction of Financial Assets and Enforcement of Security Interest Act, 2002 (SARFAESI Act, 2002)}

Reserve Bank of India has taken several steps for resolving problems of NPAs existing in Public Sector Banks. It is needless to mention that banks and financial institutions play the important role in the growth and upliftment of any economy. While doing so, the possibility of conversion of loan or advance into Non-performing asset cannot be ruled out. Therefore, Reserve bank of India taking cognizance of all these aspects keep on rolling out reforms in various areas so that these financial intermediaries can be liberated from any such problem as and when encountered. The enactment of SARFAESI Act, 2002 is one of the major and long pending demand of public sector banks. Under this act, the public sector banks are authorized to confiscate the security of borrower and sell it for recovering its dues. The Act enables the banks to recover without undergoing through rigorous process involved in court and time consuming process. The main features of SARFAESI Act, 2002 are summarized below

- The act can be used by public sector banks where NPA exceeds Rs 1 lakh or more than $20 \%$ of loan and interest accrued. In case, the amount is less than Rs 1 lakh, the provisions of this act cannot be invoked.

- The debt shall be secured and it should have been satisfying conditions laid down for classification as NPA

- The amount of banks blocked in form of NPA can be recovered without involvement of courts.

- The Act empowers banks to recover NPAs through different alternatives such as Securitisation, Asset Reconstruction and security enforcement.

- The banks are empowered to issue notice to the defaulters to pay their pending dues within sixty days of the receipt of notice.

- The defaulting borrower, if not satisfied with the notice of the bank, can approach Debt Recovery Tribunal and Debt Recovery Appellate Tribunal. However, in such a case, the borrower needs to deposit at least $50 \%$ of the dues with the tribunal. Only then, his appeal can be acceded.

- In case the defaulting borrower neither respond to the notice of the bank nor appeal to the DRT, the bank has right to take possession of the security held as mortgage. The bank can authorize or assign right of taking possession of the security to the third party.

- The banks are authorised to directly collect the money from the debtors of the defaulting borrower to settle its dues. 
- The borrower has the right to stop the bank from selling his security if pays his dues before the security are disposed of.

- The Act does not empower bank to exercise above process of security transfer in case of Agricultural land.

Once the bank takes over the property of the borrower, it informs the borrower that the bank is planning to sell the property through auction. The borrower is given opportunity to settle dues within 30 days of the notice and re acquire the assets from the bank. If the borrower fails to respond, the bank reserves the right to dispose of the asset on 'as is where is' basis. However, the banks are required to issue public notice for sale of assets so that it can get bidders at highest possible prices for the asset and the banks also need to ensure that the notice is in wide circulation among public. The banks provide bidders an opportunity to inspect the asset before sending their bids. In the notice the bank is shown as secured creditor.

In the recent budget presented in the financial year 2015, Non-Banking financial companies have also been included in the notification of SARFAESI, Act, 2002. This is seen as big boost for many NBFCs as they will also be entitled to use provisions of the Act in recovering their dues being held in the form of NPAs. The budget proposal allowed only NBFCs having asset base of Rs 2500 crore or more to be entitled for using SARFAESI, Act, 2002.Under this Act, the banks can also pool the assets secured under it and securitize them by converting them into marketable securities. These securities are then sold to qualified institutional buyers. The money realized is used for clearing dues of banks. The banks can also transfer right on secured assets to another management. The detail of the number of cases referred under SARFAESI Act, during the period 2003-04 to 2011-12 is given in Table 8 .

Table 8: Number of cases referred under SARFAESI Act during 2003-04 to 2011-12

\begin{tabular}{|c|c|}
\hline Year & Number of cases referred under SARFAESI Act \\
\hline $2003-04$ & 7544 \\
\hline $2004-05$ & 4744 \\
\hline $2005-06$ & 3534 \\
\hline $2006-07$ & 4028 \\
\hline $2007-08$ & 3728 \\
\hline $2008-09$ & 2004 \\
\hline $2009-10$ & 6019 \\
\hline $2010-11$ & 12872 \\
\hline $2011-12$ & 13365 \\
\hline
\end{tabular}

Source: Report on Trend and Progress of Banking in India, various issues, RBI 
It can be observed from the Table 8 that the number of cases referred under SARFAESI Act, has sharply increased during the period 2010-11 and 2011-12 in comparison to the preceding years. The detail of the amount involved and amount recovered under SARFAESI Act during the period 2003-04 to 2011-12 is given in Table 9 and graphically presented in Figure 7.

Table 9: Amount involved in NPAs and Recovered under SARFAESI Act

\begin{tabular}{|c|c|c|}
\hline Year & Amount Involved & Amount Recovered \\
\hline $2003-04$ & 12305 & 2117 \\
\hline $2004-05$ & 14317 & 2688 \\
\hline $2005-06$ & 6273 & 4735 \\
\hline $2006-07$ & 9156 & 3463 \\
\hline $2007-08$ & 6879 & 2988 \\
\hline $2008-09$ & 5819 & 3020 \\
\hline $2009-10$ & 9797 & 3133 \\
\hline $2010-11$ & 14100 & 3900 \\
\hline $2011-12$ & 24100 & 4100 \\
\hline
\end{tabular}

Source: Report on Trend and Progress of Banking in India, various issues, RBI

Figure 7: Amount involved in NPAs and Recovered under SARFAESI Act

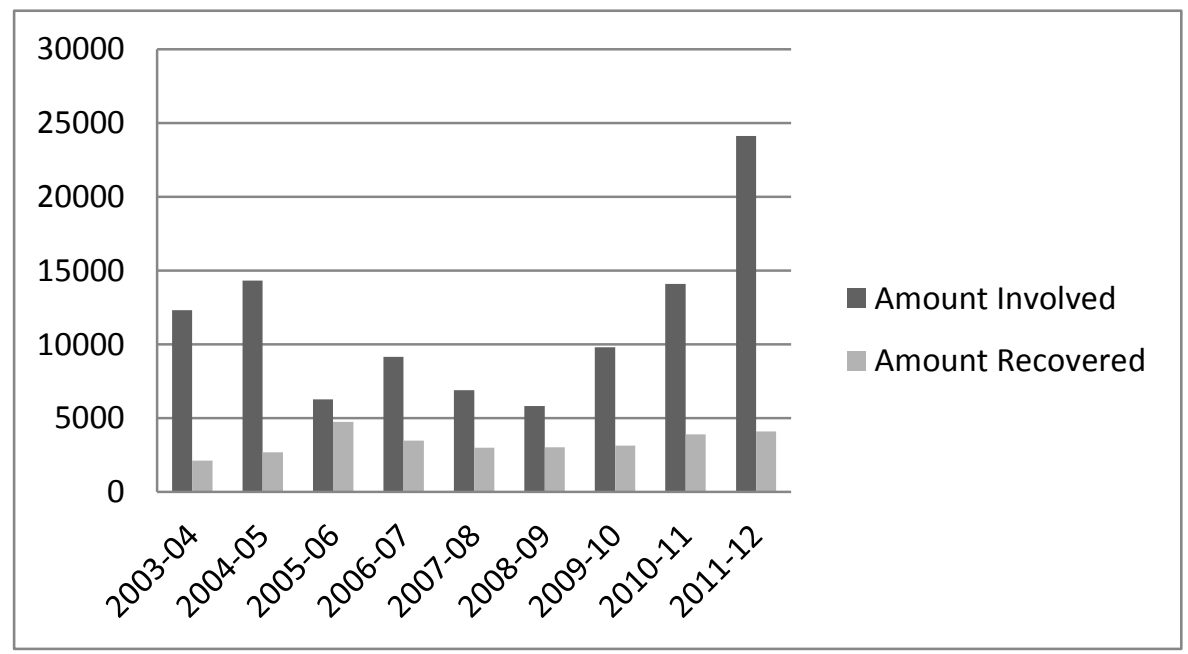

Source: Report on Trend and Progress of Banking in India, Various issues, RBI

It can be observed from the Table 9 and Figure 7 that in the initial years, this mechanism has gradually improved the recovery of the amount involved during the 
period 2003-04 to 2008-09. However, in the subsequent years, particularly during the period 2009-10 to 2011-12, the performance has not been significant. The reason which could be attributed this fact is global slowdown and stagnation in major businesses in India due to policy reasons. The efficiency of the SARFAESI Act, 2002 has been examined using the formula given below:

Efficiency of SARFAESI ACT, 2002 in recovering dues $=($ Amount recovered $/$ Amount involved) $\mathrm{x} 100$

The formula has been applied on the above information and the ratios are summarised in Table 10 below.

Table 10: Percentage of Recovery relative to Amount involved under SARFAESI Act

\begin{tabular}{|c|c|}
\hline Year & Percentage of recovery relative to amount involved \\
\hline $2003-04$ & 14.73 \\
\hline $2004-05$ & 18.05 \\
\hline $2005-06$ & 39.48 \\
\hline $2006-07$ & 38.76 \\
\hline $2007-08$ & 60.98 \\
\hline $2008-09$ & 57.04 \\
\hline $2009-10$ & 29.96 \\
\hline $2010-11$ & 37.9 \\
\hline $2011-12$ & 28.61 \\
\hline
\end{tabular}

Source: Report on Trend and Progress of Banking in India, Various issues, RBI

It can be observed that the efficiency and applicability of the SARFAESI Act, 2002 has gradually increased. During the years 2007-08 and 2008-09, the percentage of the recovery has been exceptionally high at a level of more than $50 \%$ of the amount involved. In the subsequent years, though the percentage of recovery has slightly decreased but the reason which can be attributed to this fact is the significant increase in the total number of cases referred to SARFAESI Act, 2002. Therefore, we can conclude that effectiveness of SARFAESI Act, 2002 in recovering NPA dues has not declined over time rather it has gained momentum and popularity among Public Sector Banks.

\subsection{Conclusion}

The recovery mechanism such as Lok Adalats and Debt Recovery Tribunal have proved effective in dealing with the problems of NPAs but the initiative taken by Government for enacting SARFAESI Act, 2002 has proved to be a decision taken well in 
time as the percentage of recovery has been quite significant during the period 2007-08 and 2008-09 and it has maintained its effectiveness in the subsequent years also. It is expected that these kinds of steps taken by the Government would assist public sector banks in resolving their NPAs problems of different nature and amounts.

\section{References}

Gurumoorthy, T.R. \&, Sufha, B. (2012). Non-performing assets: A study with reference to public sector banks. Indian Journal of Applied Research, 2(2), 7-9.

Jain, V. (2007). Non-performing assets in commercial banks. London, U.K.: Regal Publications.

Joshi, A. (2003). Analysis of NPAs of IFCI Ltd. Social Science research Network (SSRN) Retrieved from https://ssrn.com/abstract=2810785

Joshi, N. C. (2000). Urgent need for recovery of debts. Civil Services Chronicle, 5(10), 25-27.

Kumar, A. (2017). A study on effectiveness of recovery channels for the recovery of NPAs: A case study on scheduled commercial banks in India. International Journal of Recent Scientific Research, 8(3), 16200-16205.

Laveena \&, Guleria, K. S. (2016). A Study of Non-Performing Assets of Public Sector Banks in India. International Journal of Research in Engineering, IT and Social Science, $6(4), 26-34$.

Mahajan, P. (2014). Non-performing assets: A study of public, private and foreign sector banks in India. Pacific Business Review International, 7(7), 9-16.

Rajeev, M. \&, Mahesh, H. P. (2010). Banking sector reforms and NPA: A study of Indian commercial banks. Institute for Social and Economic Change Working Paper252.

Rao, M. \&, Patel, A. (2015). A study on Non-performing assets management with reference to public sector banks, private sector banks and foreign banks in India. Journal of Management and Science, 5(1), 30-43. 
Satpal. (2014). A comparative study of Non-performing assets in public and private sector banks in the new age of technology. International Journal of Current Engineering and Technology, 4(4), 2468-2475.

Shalini, H.S. (2013). A study on causes and remedies for NPAs in Indian public sector banks with special reference to agricultural development branch, State Bank of Mysore. International Journal of Business and Management Invention, II(1), 26-38.

Sharma, M. (2001). NPA management redefined. Indian Management, February 01. Retrieved from https://ssrn.com/abstract=2810849

Singh, V. R. (2016). A study of Non-performing assets of commercial banks and its recovery in India. Annual Research Journal of SCMS, 4(3), 110-125.

Singla, H.K. (2008). Financial performance of banks in India. The ICFAI Journal of Bank Management, 7(1), 50-62. 